\title{
Direct Electrochemistry of Heme Proteins on Electrodes Modified with Didodecyldimethyl Ammonium Bromide and Carbon Black
}

\author{
Elena V. Suprun, ${ }^{* \mathrm{a}}$ Fabiana Arduini, ${ }^{\mathrm{b}}$ Danila Moscone, ${ }^{\mathrm{b}}$ Giuseppe Palleschi, ${ }^{\mathrm{b}}$ Victoria V. Shumyantseva, ${ }^{\mathrm{a}}$ \\ Alexander I. Archakov ${ }^{\mathrm{a}}$ \\ a Institute of Biomedical Chemistry, Russian Academy of Medical Sciences, Pogodinskaya St. 10, Moscow, 119121 Russia \\ b Dipartimento di Scienze e Tecnologie Chimiche, Università di Roma Tor Vergata, via della Ricerca Scientifica, Rome, 00133 Italy \\ *e-mail: lenasuprun@mail.ru
}

Received: July 15, 2012

Accepted: August 11, 2012

\begin{abstract}
A novel matrix based on commercially available carbon black (CB) N220 and didodecyldimethyl ammonium bromide (DDAB) was shown to be a reliable support for direct electron transfer reactions between screen printed electrode (SPE) and Fe(III)-heme proteins. Cytochrome $c$ (cyt c), myoglobin (Mb), horseradish peroxidase (HRP) and cytochromes P450 (CYP 51A1, CYP 3A4, CYP 2B4) generated well-shaped cyclic voltammograms on SPE/CB/ DDAB electrodes (both in solution and in immobilized state). The attractive performance characteristics of $\mathrm{CB}$ modified electrodes are advantageous over single-walled carbon nanotubes (SW CNT) based ones. The achieved direct electrochemistry of heme proteins on $\mathrm{CB} / \mathrm{DDAB}$-modified electrodes provided successful elaboration of the immunosensor for cardiac $\mathrm{Mb}$. The immunosensor showed applicability for diagnostics of myocardial infarction displaying significant difference in cardiac $\mathrm{Mb}$ content of human blood plasma samples taken from the corresponding patients.
\end{abstract}

Keywords: Carbon black, Cardiac myoglobin, Didodecyldimethyl ammonium bromide, Direct electron transfer, Heme protein

DOI: 10.1002/elan.201200359

\section{Introduction}

In supporting living organisms on the earth, heme proteins play a vital role in various life processes. These include the transport and storage of molecular oxygen by hemoglobin $(\mathrm{Hb})$ and by $\mathrm{Mb}$, the transfer of electrons from respiratory substrates by cytochromes and the terminal oxidation with $\mathrm{O}_{2}$ by cytochrome $c$ oxidase, the decomposition of hydrogen peroxide by catalase, the oxidation of organic substances with $\mathrm{H}_{2} \mathrm{O}_{2}$ by peroxidase, the hydroxylation of organic substances through dioxygenation by cytochrome P450, the synthesis of nitric oxide from L-Arg by NO synthase, and so forth. As a matter of fact, all these different functions are primarily based upon the oxidation-reduction properties of the heme iron in itself [1]. Based on their unique catalytic and electrochemical properties, the heme proteins are finding an increasing application in biosensor construction for the detection of different biologically active species. On the other hand, determination of heme proteins (such as $\mathrm{Hb}$, $\mathrm{Mb}$ ) in very small concentrations in human biological fluids is still a highly topical issue.

Heme proteins based biosensors operating through direct electron transfer reactions (which electrons being directly transmitted between the electrode and the heme iron) belong to the third-generation biosensors $[2,3]$. However, such electrocatalytic reactions can only be ac- complished by using special electrode surface modifiers [4-6]. Efficiency of direct electron transfer between the electrode and the heme depends on electrode material, electrode surface modification and proper orientation of the protein active center on the electrode.

Carbon materials, owing to the availability of different conducting allotropes, the good thermal and electrochemical stability, and a wide range of carbon microstructures of varying hardness, cost, and reactivity, are widely used in electrochemistry for electrode construction and modification. "Classical" carbon materials are based on graphite, glassy carbon, and CB. Recently developed materials can be subdivided into microfabricated carbon, conducting diamond, fibers and nanotubes, and carbon composites. The propensity of carbon to adsorb molecules from solution and the presence of surface oxides permit electrocatalytic reactions on carbon electrodes that are weaker or absent on metal electrodes. The $\mathrm{Fe}(\mathrm{III}) /(\mathrm{II})$ redox reaction strongly depends on the presence of surface oxides on carbon and is inhibited significantly if they are absent or obscured by adsorbates. The Fe-O bond in hydrated $\mathrm{Fe}$ (III) changes length upon reduction, and this process is facilitated by transient interactions with surface oxides [7].

Carbon materials are among the most common in bioelectrochemistry due to their (i) electrochemically inert surface and (ii) high sorption ability. CB based electrodes, 
graphite rods, edge plan pyrolytic graphite, carbon filament materials and even screen printed carbon electrodes are used as support for bioelectrocatalytic systems. Prior to enzyme immobilization, hydrophobic materials (carbon filament, CB) have to be hydrophilized chemically or electrochemically, with subsequent thorough washing - to prevent protein coagulation [3].

$\mathrm{CB}$ is virtually pure elemental carbon in the form of colloidal particles that are produced by incomplete combustion or thermal decomposition of gaseous or liquid hydrocarbons under controlled conditions (www.carbonblack.org). While diameters of primary particle (near spherical building blocks of CB) are generally in the 10 $300 \mathrm{~nm}$ range, $\mathrm{CB}$ products as placed into commerce (the final products) are agglomerates, which are much larger in size (100-1000 nanometers in diameter).

In late 70 s of the $\mathrm{XX}$ century the direct bioelectrocatalysis was discovered using $\mathrm{CB}$ electrode for the enzyme laccase immobilization [8]. In this decade, CB showed itself as an advantageous carbon material in analytical electrochemistry due to its low cost manufacturing, simple treatment and electrocatalytic properties towards many biologically active compounds such as ascorbic acid $[9,10]$, dopamine [10], reduced form of nicotinamide adenine dinucleotide (NADH) [11,12], benzoquinone $[11,12]$, epinephrine $[11,12]$, cysteine and thiocholine [13], some heavy metals (Cd(II), $\mathrm{Pb}(\mathrm{II})$ ) [10] and hydrogen peroxide $[10,12]$. CB modification of the sensors provides an improvement in terms of the low peak-to-peak separation and an increase of peak current intensity of the compound tested. A sensor based on polyethylenegraphitized CB as an electrochemical detector in a highperformance liquid chromatography (HPLC) analytical system was developed. It showed a higher signal-to-noise ratio for several compounds tested such as phenol, chlorophenols and hydroquinone [14]. The suitability of CB for biosensor applications was demonstrated with tyrosinase to produce a biosensor that was challenged in amperometric mode with catechol. The highest sensitivity, equal to $625 \mathrm{nA} / \mathrm{mM}$, coupled with the lowest detection limit of $0.008 \mathrm{mM}$, was observed [9]. Reagentless enzyme biosensors based on the quinohemoprotein alcohol dehydrogenase and graphitized $\mathrm{CB}$, suitable for determination of ethanol, glucose and hydrogen peroxide (with electrocatalytic oxidation taking place at $0.1-0.4 \mathrm{~V}$ vs. $\mathrm{Ag} / \mathrm{AgCl}$ ), were designed using screen-printing technique by Razumiene et al. [15]. The direct electrochemical reaction of $\mathrm{Hb}$ adsorbed on the surface of $\mathrm{CB}$ with an underlying glassy carbon electrode was first reported by $\mathrm{Ma}$ and coworkers [16]. CB powders were dispersed thoroughly in 0.1 wt. $\%$ cetyltrimethylammonium bromide (CTAB) solution which served as a dispersant to prevent the CB powders aggregation following ultrasonication. The $\mathrm{Hb}$ molecules were adsorbed on the surface of $\mathrm{CB}$ powders during mixing. The immobilized $\mathrm{Hb}$ retained its bioelectrocatalytic activity for the reduction of $\mathrm{H}_{2} \mathrm{O}_{2}$.

Liquid crystal surfactant films for electrochemical catalysis were thoroughly studied by Rusling's group [17]. It was shown that standard electron-transfer rate constants for the $\mathrm{Fe}(\mathrm{III}) / \mathrm{Fe}(\mathrm{II})$ redox couple of $\mathrm{Mb}$ were about 1000 -fold higher in liquid crystal films of didodecyldimethyl ammonium bromide on pyrolytic graphite electrodes than in aqueous solutions [18]. Mb retains the heme iron and near-native conformation in DDAB films [19]. The electron transfer rate of the Hb heme's $\mathrm{Fe}(\mathrm{III}) / \mathrm{Fe}(\mathrm{II})$ couple was much greater in DDAB films than it was on bare edge-plane pyrolytic graphite electrodes or electrodes modified with mediators with $\mathrm{Hb}$ in solution [20]. Electronic absorbance linear dichroism showed that $\mathrm{Hb}$ and $\mathrm{Mb}$ are preferentially oriented in the films $[19,20]$. Therefore, surfactants (DDAB, CTAB) provide good adsorption of heme proteins and serve not only as dispersants to prevent the powder aggregation but also as catalysts of electrochemical reactions.

In this work, a novel matrix based on commercially available CB N220 and surfactant DDAB was tested for registration of direct electrochemical reactions of heme proteins. Several heme proteins from different classes were chosen as the objects of this investigation: cyt $c$, $\mathrm{Mb}, \mathrm{HRP}$ and CYPs. For all proteins tested the wellshaped reduction and oxidation peaks were registered by cyclic (CV) and square wave voltammetry (SWV). The characteristics of $\mathrm{CB}$ as an electrode surface modifier were advantageous over SW CNT ones. Based on direct electrochemistry of heme proteins on CB-modified electrodes, the immunosensor for cardiac $\mathrm{Mb}(\mathrm{cMb})$ detection was developed. The ability of this newly-obtained device to detect myoglobin in human plasma may find an application in diagnostics of acute myocardial infarction (AMI).

\section{Experimental}

\subsection{Apparatus and Electrochemical Measurements}

Cyclic voltammetry and square wave voltammetry measurements were performed using an Autolab electrochemical system PGSTAT-12 (Eco Chemie, Utrecht, The Netherlands) equipped with GPES software (Eco Chemie, Utrecht, The Netherlands). Electrochemical impedance spectroscopy (EIS) measurements were carried out in the same electrochemical cell with a PC-controlled Autolab and FRA software (Eco Chemie, Utrecht, The Netherlands). A sinusoidal voltage perturbation of $10 \mathrm{mV}$ amplitude was applied over the frequency range $10 \mathrm{kHz}$ to $0.01 \mathrm{~Hz}$ with 10 measurement points per frequency decade. For the fitting of the data obtained by EIS, Zviews software (Scribner Associates, Inc.) has been used with the Randles equivalent circuit [21]. Screen-printed graphite electrodes were home made by a 245 DEK (Weymouth, UK) screen-printing machine. Graphite based ink (Electrodag 423 SS) from Acheson (Milan, Italy) for printing the working and counter electrode, and silver ink (Electrodag $477 \mathrm{SS}$ ) for the pseudo-reference electrode were used. The substrate was a flexible polyester film (Autostat HT5) obtained from Autotype Italia 
(Milan, Italy) by using the procedure and materials described earlier [12]. The electrodes were produced in foils, each containing 48 electrodes. The diameter of the working electrode was $0.3 \mathrm{~cm}$ resulting in a geometric area of $0.071 \mathrm{~cm}^{2}$. All potentials were referred to the $\mathrm{Ag}$ screen-printed pseudo-reference electrode. All electrochemical experiments were carried out at room temperature $\left(20-25^{\circ} \mathrm{C}\right)$ in a $100-\mu \mathrm{L}$ drop put onto the SPE so as to cover all 3 electrodes.

\subsection{Chemicals and Proteins}

The following heme proteins were used: equine myoglobin from skeletal muscles (Serva); horse heart cytochrome $c$ (Merck); horseradish peroxidase (HRP, Sigma, 1000 units/mg solid, using ABTS); cytochrome P450 51A1 (human, recombinant, Gene ID: 1595 CYP 51A1, $165 \mu \mathrm{M}$, in $300 \mathrm{mM}$ potassium-phosphate buffer, $\mathrm{pH} 7.2$, containing $20 \%$ glycerol, $0.2 \%$ CHAPS and $1 \mathrm{mM}$ DTT); cytochrome P450 3A4 (human, recombinant, Gene ID: 1576 CYP 3A4, $165 \mu \mathrm{M}$, in $550 \mathrm{mM}$ potassiumphosphate buffer, $\mathrm{pH} 7.2$, containing $20 \%$ glycerin, $0.2 \%$ CHAPS and $1 \mathrm{mM}$ DTT). CYP 51A1 and CYP $3 \mathrm{~A} 4$ were kindly presented by Prof. S. A. Usanov (Institute of Bioorganic Chemistry, Minsk, Belarus). Cytochrome P450 2B4 $(100 \mu \mathrm{M})$ was isolated from the microsomal fraction of rabbit liver induced by phenobarbital and purified as described in [22]. Concentration of P450 2B4 was determined by formation of a complex of the cytochrome P450's reduced form with carbon monooxide using the extinction coefficient $\varepsilon_{450}=91 \mathrm{mM}^{-1} \mathrm{~cm}^{-1}$ [23]. Mouse antihuman myoglobin, cardiac (anti-cMb, mass concentration $1.05 \mathrm{mg} / \mathrm{mL}, \mathrm{M} 9800-16 \mathrm{~A}$ ) was purchased from USBiological.

Plasma samples were obtained from healthy donors and patients with AMI. Informed signed consent was obtained from each of the patients. Plasma was collected after centrifugation of blood with EDTA as anticoagulant for $10 \mathrm{~min}$ at $3000 \mathrm{rpm}$. Cardiac myoglobin concentration as indicator of AMI was determined in each sample with the bench-top lateral flow immunoassay RAMP (Response Biomedical Corp) according to the instruction. The samples from the bank of plasma of healthy donors and patients with AMI with cMb mass concentrations $190 \pm 19$ and $350 \pm 35 \mathrm{ng} / \mathrm{mL}$ were used for testing [24].

Salts $\left(\mathrm{KH}_{2} \mathrm{PO}_{4}, \mathrm{KCl}, \mathrm{NaCl}\right.$, potassium ferrocyanide trihydrate, potassium hexacyanoferrate (III)) were from Sigma-Aldrich and Carlo Erba reagenti. Didodecyldimethylammonium bromide was from Sigma-Aldrich. Solvents: Chloroform was from Carlo Erba reagenti and $\mathrm{N}, \mathrm{N}$-dimethylformamide (DMF) was from Merck.

CB N220 was obtained from Cabot Corporation (Ravenna, Italy). As reported by the manufacturer, CB particles used had a diameter comprised between 19 and $29 \mathrm{~nm}$ with a surface area of $124 \mathrm{~m}^{2} /$ gas measured by BET method ( $\mathrm{N}_{2}$ absorption). Single wall carbon nanotubes were from NanoLab (SW CNT, $\mathrm{COOH}$ functional- ized, lot. PD30L5-20-COOH). All the chemicals were of analytical grade.

\subsection{Solutions}

Electrochemical experiments were carried out in phosphate buffer (PB) containing: $0.1 \mathrm{M} \mathrm{KH}_{2} \mathrm{PO}_{4}+50 \mathrm{mM}$ $\mathrm{NaCl}, \mathrm{pH}$ 6.5. $5 \mathrm{mM} \mathrm{K}_{3}\left[\mathrm{Fe}(\mathrm{CN})_{6}\right]$ in $0.1 \mathrm{M} \mathrm{KH}_{2} \mathrm{PO}_{4}+1 \mathrm{M}$ $\mathrm{KCl}$ ( $\mathrm{pH}$ 7.4) was used to evaluate the efficient surface area of the working electrode. $5 \mathrm{mM} \mathrm{K}_{3}\left[\mathrm{Fe}(\mathrm{CN})_{6}\right]+5 \mathrm{mM}$ $\mathrm{K}_{4}\left[\mathrm{Fe}(\mathrm{CN})_{6}\right]$ in $0.05 \mathrm{M}$ phosphate buffer $+0.1 \mathrm{M} \mathrm{KCl}$ was used as supporting electrolyte for electrochemical impedance spectroscopy. Heme proteins $(\mathrm{Mb}$ and cyt $c$ ) were tested directly or immobilized onto the electrode surface from $500 \mu \mathrm{M}$ or $1 \mathrm{mM}$ stock solutions in PB. HRP $(2160 \mathrm{U} / \mathrm{mL})$ was dissolved in citrate buffer, $\mathrm{pH}$ 5.0. For electrode modification $0.1 \mathrm{M}$ solution of DDAB in chloroform was used.

\subsection{Preparation of SW CNT Dispersion (Mass Concentration $1 \mathrm{mg} / \mathrm{mL}$ )}

SW CNT were oxidized according to the procedure described earlier in [25]. For oxidation $4 \mathrm{mg}$ of SW CNT were weighted into a glass bottle, then $1 \mathrm{~mL}$ of $\mathrm{HNO}_{3}$ (conc. $65 \%$ ) and $3 \mathrm{~mL}$ of $\mathrm{H}_{2} \mathrm{SO}_{4}$ (conc. $95 \%$ ) were added. Resulting mass concentration of SW CNT was $1 \mathrm{mg} / \mathrm{mL}$ of the acid mixture, and the acid ratio $\mathrm{HNO}_{3}$ : $\mathrm{H}_{2} \mathrm{SO}_{4}$ was $1: 3$. The bottle was hermetically closed with a cap, then put into ultrasonic bath and ultrasonicated for 6 hours, at $50^{\circ} \mathrm{C}$. After sonication, the resulting mixture was split up into 1.5 -mL eppendorfs, with $0.5 \mathrm{~mL}$ of the mixture being added to each eppendorf (the resulting content was $0.5 \mathrm{mg}$ of SW CNT per eppendorf). The eppendorfs were centrifuged for $20 \mathrm{~min}$ at a speed of $12000 \mathrm{rpm}$. After centrifugation the acidic solution was gently removed from the eppendorfs with a micropipette and the nanotubes cleaned with distillated water. To do that, $1 \mathrm{~mL}$ of water was added to each eppendorf, centrifuged for $20 \mathrm{~min}$ at the speed $12000 \mathrm{rpm}$ and removed gently with a micropipette. The washing procedure was repeated 3 times. After removing the water in the last iteration of the cleaning, the eppendorfs with nanotubes were air-dried. The oxidized nanotubes were dispersed in DMF-water solution at the ratio $1: 1$ - by adding $0.5 \mathrm{~mL}$ of the solution into each eppendorf - and sonicated at 59 $\mathrm{KHz}$ for $120 \mathrm{~min}$ at $50^{\circ} \mathrm{C}$. The resulting mass concentration of SW CNT was $1 \mathrm{mg} / \mathrm{mL}$.

\subsection{Preparation of CB Dispersion (Mass Concentration $1 \mathrm{mg} / \mathrm{mL}$ )}

To prepare the $\mathrm{CB}$ dispersion, $10 \mathrm{mg}$ of freshly prepared CB powder was added to $10 \mathrm{~mL}$ of DMF - water mixture $(1: 1)$ and then sonicated for $60 \mathrm{~min}$ at $59 \mathrm{kHz}$. 


\subsection{SPE Modification by CB or SW CNT}

The SPE was modified with $\mathrm{CB}(\mathrm{SPE} / \mathrm{CB})$ or with $\mathrm{CNTs}$ (SPE/CNT) as follows: $6 \mu \mathrm{L}$-volume of the $\mathrm{CB}$ or $\mathrm{CNT}$ dispersions was pipetted onto the working electrode surface of the SPE by three steps of $2 \mu \mathrm{L}$ each. After each deposition, the solvent was allowed to evaporate.

\subsection{Preparation of Electrochemical Biosensors (SPE/CB or CNT/ DDAB/(Heme Protein))}

To the surface (bare or modified by $\mathrm{CB}$ or SW CNT) of the working graphite electrode $0.25 \mu \mathrm{L}$ of $0.1 \mathrm{M}$ DDAB were added; after evaporation of chloroform, heme protein $(\mathrm{Mb}$, cyt $c$, cytochrome $\mathrm{P} 450$ or HRP) was immobilized onto the SPE/CB (CNT)/DDAB: $0.25 \mu \mathrm{L}$ of protein solution was dropped onto the electrode surface and kept at $4{ }^{\circ} \mathrm{C}$ overnight. SPE/DDAB, SPE/CB/DDAB or SPE/ $\mathrm{CNT} / \mathrm{DDAB}$ were used in control experiments or experiments with protein solutions.

\subsection{Preparation of Electrochemical Immunosensors (SPE/CB/DDAB/anti-cMb)}

Immunosensors based on $\mathrm{CB}$ modified electrodes were prepared according to the principal circuit described in [24,26]. $0.25 \mu \mathrm{L}$ of $0.1 \mathrm{M}$ DDAB were deposited on the surface of SPE/CB $(6 \mu \mathrm{L})$; after evaporation of chloroform, the antibodies were immobilized onto the SPE/ DDAB: $0.25 \mu \mathrm{L}$ of $105 \mathrm{ng} / \mu \mathrm{L}$ anti-cMb solution in $\mathrm{PB}$ ( $\mathrm{pH}$ 6.5) were dropped onto the electrode surface and kept at $4^{\circ} \mathrm{C}$ overnight.

\subsection{Mb Determination Procedure}

The $0.25-\mu \mathrm{L}$ sample of $\mathrm{Mb}$ in $\mathrm{PB}$ (or undiluted human blood plasma) was loaded onto the sensor surface (i.e. onto SPE/CB/DDAB, SPE/DDAB or SPE/CB/DDAB/ anti-cMb, SPE/DDAB/ anti-cMb). Sensor was allowed to stay for $15 \mathrm{~min}$ at $37^{\circ} \mathrm{C}$. Then electrochemical measurements were carried out at $25^{\circ} \mathrm{C}$. The $100-\mu \mathrm{L}$ drop of $\mathrm{PB}$ was put on the electrode surface to cover all three electrodes (working, counter and reference); 5 min after, the electrochemical registration of the signal (cathodic peak area or current at $E_{\max } \approx-250 \mathrm{mV}$ ) was carried out by SWV. The following experimental parameters of SWV were used: initial potential, $E_{\mathrm{i}}=0.1 \mathrm{~V}$; end potential, $E_{\mathrm{e}}=$ $-0.6 \mathrm{~V}$; pulse height, $\Delta E_{\mathrm{p}}=20 \mathrm{mV}$; step potential, $\Delta E_{\mathrm{s}}=$ $5 \mathrm{mV}$; square wave frequency, $f=10 \mathrm{~Hz}$.

\section{Results and Discussion}

\subsection{Ferricyanide/Ferrocyanide Redox Couple on SPEs Modified with CB or SW CNT}

Examination of electron transfer kinetics on SPE/CB and SPE/SW CNT was performed using $5 \mathrm{mM} \mathrm{K}_{3}\left[\mathrm{Fe}(\mathrm{CN})_{6}\right]$ in phosphate buffer ( $\mathrm{pH}$ 7.4) by applying cyclic voltammetry at different scan rates in the range between 0.005 and $0.05 \mathrm{~V} / \mathrm{s}$. Figure 1 illustrates CVs of ferricyanide ion reduction and ferrocyanide oxidation on bare SPE and SPEs modified with CB and SW CNT ( $6 \mu \mathrm{L}$ of dispersion/electrode).

The electrochemical characteristics of the ferricyanide/ ferrocyanide redox couple on SPE and SPEs modified with CB or SW CNT are summarized in Table 1. Modifi-

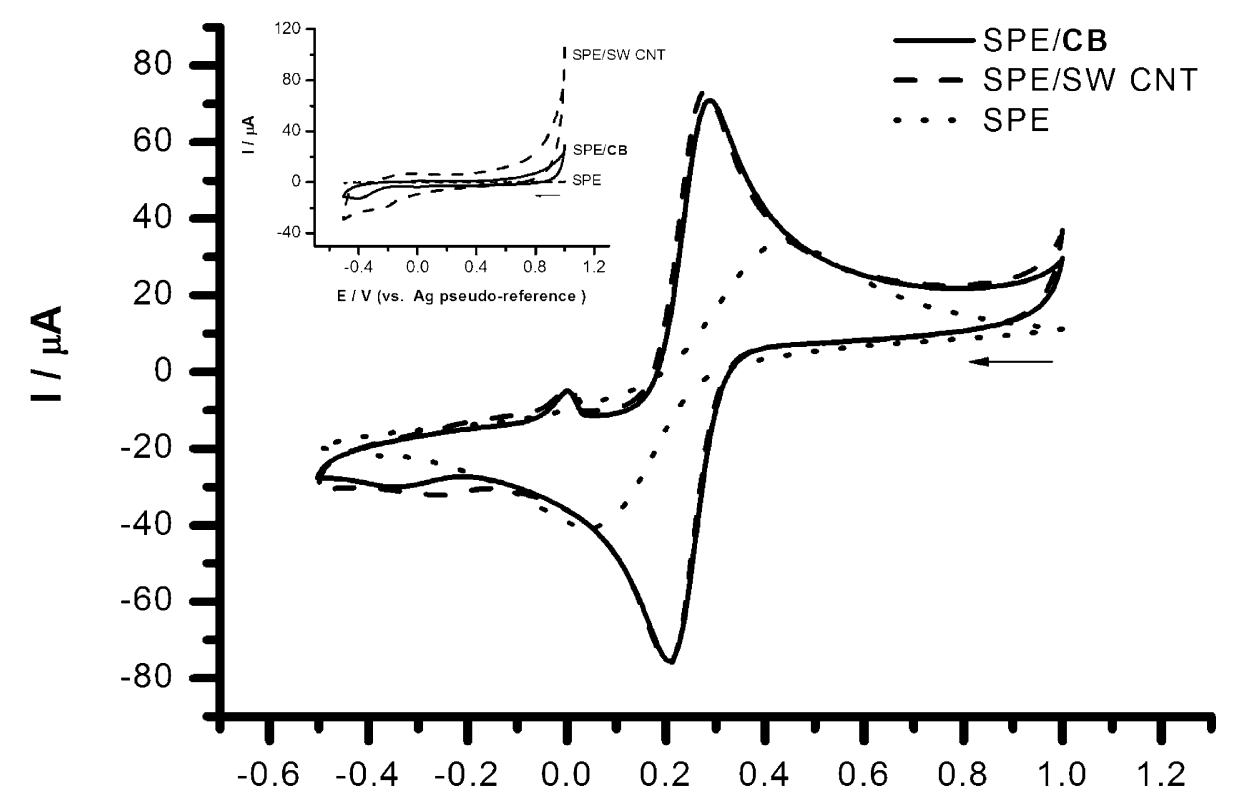

\section{E I V (vs. Ag pseudo-reference)}

Fig. 1. $\mathrm{CVs}$ of $5 \mathrm{mM} \mathrm{K}_{3}\left[\mathrm{Fe}(\mathrm{CN})_{6}\right]$ (in $0.1 \mathrm{M} \mathrm{KH}_{2} \mathrm{PO}_{4}+1 \mathrm{M} \mathrm{KCl}$, pH 7.4) using bare SPE, SPE/CB and SPE/SW CNT. Inset: Baselines for bare SPE, SPE/CB and SPE/SW CNT. Potential scan rate is $50 \mathrm{mV} / \mathrm{s}$, from 1000 to $-500 \mathrm{mV}$. 
cation of the SPE surface with CB or SW CNT significantly increased the rate of the $\mathrm{Fe}(\mathrm{III}) / \mathrm{Fe}$ (II) redox process. SPEs modified with 2,4 and $6 \mu \mathrm{L}$ of CB or SW CNT dispersions were tested. For both dispersions the $6-\mu \mathrm{L}$ volume was found saturated for SPE modification (data not shown). Following CB or SW CNT modifications, the effective surface area of electrodes was enlarged twofold ( $6 \mu \mathrm{L}$ of dispersion/electrode). Based on Randles-Sevcik's equation with the diffusion coefficient $D=5.9 \times$ $10^{-5} \mathrm{~cm}^{2} / \mathrm{s}$ [27], the effective surface areas $(A)$ of bare SPE and SPEs modified with CB and SW CNT were estimated (Table 1). As is clear from Figure 1, the ferricyanide reduction-ferrocyanide oxidation peaks on SPE/CB and SPE/SW CNT are almost equal (the equal amounts $(6 \mu \mathrm{L})$ of SW CNT or CB dispersion were put on SPEs), but the baseline for SPE/CB appeared to be much lower than that for SPE/SW CNT. A small peak-to-peak separation $\left(\Delta E_{\mathrm{p}}\right)$ with increasing scan rates was observed for both SPE/CB and SPE/SW CNT (Table 1). Such behavior of the ferricyanide ions suggests a quasi reversible mechanism of electrochemical reaction. The formal potential $\left(E^{\prime \prime}\right)$ and the peak-to-peak separation for the ferri/ferrocyanide redox couple on SPE/CB were nearly equal to those obtained on SPE/SW CNT (with $v=50 \mathrm{mV} / \mathrm{s}$ ) (Table 1). The current of the anodic and cathodic peaks increased linearly with the square root of the scan rate $(5-50 \mathrm{mV} / \mathrm{s})$, indicating that the process was diffusion controlled for all electrodes under study (data not shown). Based on Nicholson's theory [28], the heterogeneous rate constants $\left(k^{\circ}\right)$ for the ferricyanide/ferrocyanide redox couple on bare and modified electrodes were calculated - proceeding from the assumption that $D_{\mathrm{O}}=D_{\mathrm{R}}=$ $5.9 \times 10^{-5} \mathrm{~cm}^{2} / \mathrm{s}$ and an electrochemical transfer coefficient $\alpha=0.5$, since the $I_{\mathrm{p}, \mathrm{a}} / I_{\mathrm{p}, \mathrm{c}}$ value is very close to unity (Table 1).

Table 1. Electrochemical characterization of bare SPE, SPE/CB and SPE/SW CNT by using the ferricyanide/ferrocyanide redox couple: $5 \mathrm{mM} \mathrm{K}_{3}\left[\mathrm{Fe}(\mathrm{CN})_{6}\right]$ in phosphate buffer ( $\left.\mathrm{pH} 7.4\right)$; $\mathrm{CV}$, from 1000 to $-500 \mathrm{mV}$; scan rate, $50 \mathrm{mV} / \mathrm{s}$.

\begin{tabular}{llll}
\hline Characteristics & SPE & SPE/CB & SPE/SW CNT \\
\hline$A\left(\mathrm{~cm}^{2}\right)$ & $0.016 \pm 0.002[\mathrm{a}]$ & $0.032 \pm 0.003$ & $0.032 \pm 0.003$ \\
$E^{\circ \prime}(\mathrm{V})$ & 0.244 & 0.246 & 0.245 \\
$\Delta E_{\mathrm{p}}(\mathrm{V})$ & 0.371 & 0.078 & 0.071 \\
$k^{\circ}(\mathrm{cm} / \mathrm{s})$ & $1.0 \pm 0.1 \times 10^{-2}$ & $1.4 \pm 0.1 \times 10^{-2}$ & $1.9 \pm 0.2 \times 10^{-2}$ \\
\hline
\end{tabular}

[a] The geometric area is 0.071 .

The more intensive electron transfer of the ferricyanide/ferrocyanide redox couple with modified SPEs was again confirmed by using EIS. The spectra obtained at the open circuit potential were plotted as Nyquist plot $\left(-Z_{\mathrm{i}}\right.$ vs. $\left.Z_{\mathrm{r}}\right)$ in the complex plane (data not shown). The relevant parameter in these experiments is the charge transfer resistance, $R_{\mathrm{ct}}$, which represents the difficulty of electron transfer of a ferro/ferricyanide redox probe between the solution and the electrode, providing information about the electrochemical interphase. Fitting of spec- tra was done using a Randles equivalent electrical circuit which is comprised of the electrolyte resistance, $R_{\mathrm{s}}$, in a series with a parallel combination of $R_{\mathrm{ct}}, Z_{\mathrm{w}}$ (diffusion of the analytes in solution) and constant phase element (CPE). It was necessary to introduce the CPE, because of the non-homogeneous surfaces of both the bare and modified SPEs. Using the SPE/CB, we have obtained the $R_{\text {ct }}$ value equal to $222 \pm 27 \Omega$ instead of $38 \pm 2 \Omega$ in case of SPE/SWCNT; the both values were much lower than the $R_{\mathrm{ct}}$ value for bare SPE $(4004 \pm 6 \Omega)$ reported in our previous paper [12]. Clearly, modification of the working electrode surface with a layer of CB or SW CNT can markedly promote the electrochemical reaction of the $\mathrm{Fe}(\mathrm{III}) / \mathrm{Fe}(\mathrm{II})$ couple.

Electrochemical studies of ferricyanide ions in solutions have shown that analytical characteristics of the electron transfer for SPE/CB are comparable to those for SPE/SW CNT and, also, to the earlier reported data on SW CNT and MW CNT modified electrodes [27,29]. Moreover, as was shown earlier by Compton group, carbon nanotubes and graphite powder modified basal plane pyrolytic graphite demonstrated similar electrocatalytic behavior toward NADH, epinephrine and norepinephrine [30]. As is known from our previous studies and literature data, the list of analytes, in relation to which $\mathrm{CB}$ exhibited the electrocatalytic properties (ascorbic acid, dopamine, $\mathrm{NADH}$, benzoquinone, epinephrine, cysteine and thiocholine [9-13]), correlates with the list of compounds for CNT-modified electrodes [31], which also confirms the similar electrocatalytic behavior of CB and CNT on the electrode surface. Therefore, like other carbon materials, CB provides enlargement of the effective surface area of working electrode and exhibits high-quality electrochemical properties with enhanced currents and reduced peakto-peak separations upon voltammetry. One very important $\mathrm{CB}$ advantage is a large number of edge-plane/defect sites in its structure - as was shown for the open ends of nanotubes, for the basal plane highly ordered pyrolytic graphite [32] and, also, for the SPE surface [33]. Raman spectrometry of $\mathrm{CB}$ revealed the presence of $\mathrm{D}$ and $\mathrm{G}$ bands, while the $I_{\mathrm{D}} / I_{\mathrm{G}}$ ratio - a measure of the number of disordered and defect sites - was equal to 0.96 : this value is comparable to the literature data reported for $\mathrm{CNT}$ [11].

\subsection{Direct Electrochemistry of Heme Proteins on DDAB/CB/SPE}

Reduction-oxidation $\mathrm{CVs}$ for $\mathrm{Mb}$ and cyt $c$ solutions were registered with SPE, SPE/CB, SPE/DDAB and SPE/CB/ DDAB. Reduction of $\mathrm{Fe}$ (III)-heme of Mb was not observed on the bare SPE, and the reduction-oxidation process of the $\mathrm{Fe}$ (III)-heme of cyt $c$ was very slow. The modification of the electrode surface with $\mathrm{CB}$ increased the baseline current but did not significantly change the signal-to-noise ratios and rates of the electron transfer processes. In agreement with Rusling's work [18], to promote direct electron transfer between $\mathrm{Fe}$ (III)-heme and 

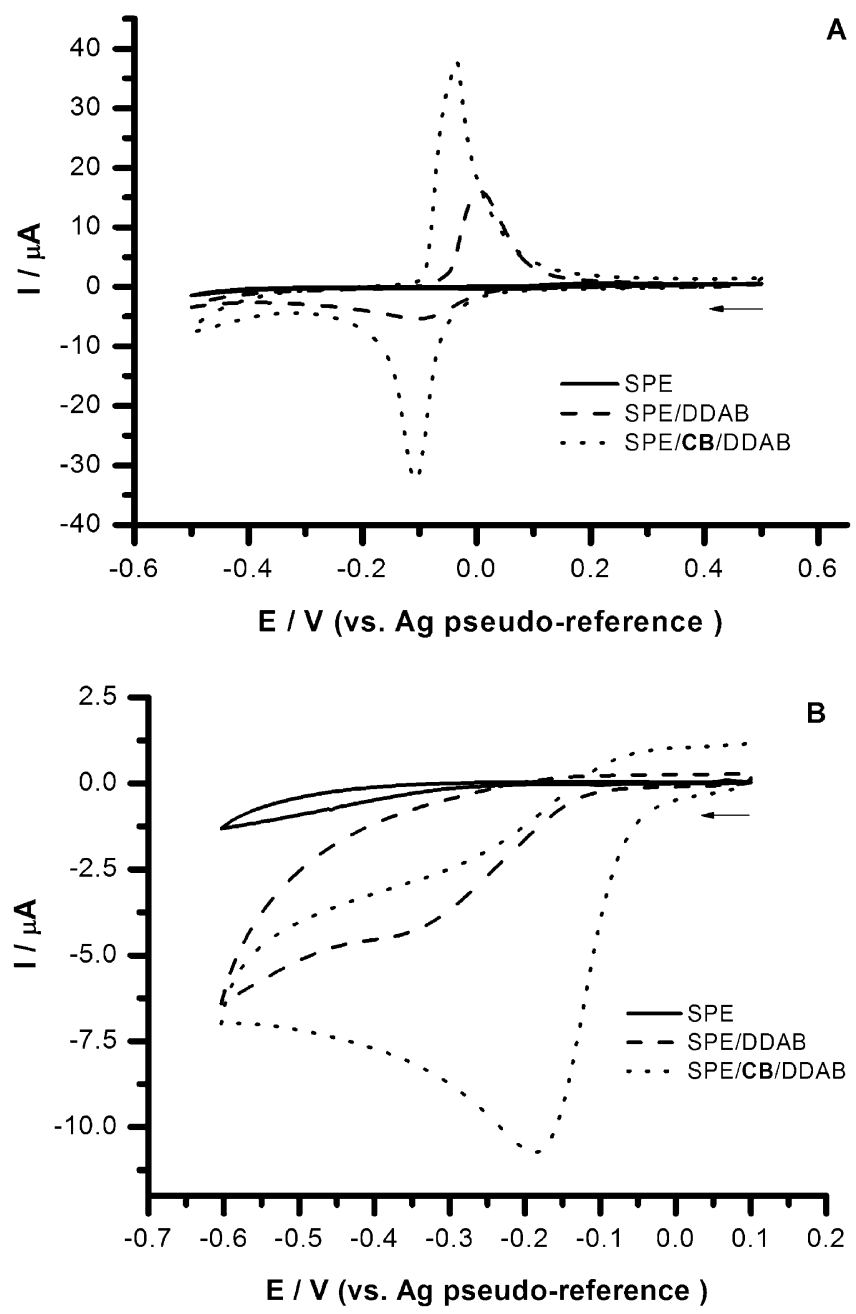

Fig. 2. CVs of $500 \mu \mathrm{M}$ cyt $c$ (A) and $500 \mu \mathrm{M} \mathrm{Mb}$ (B) in $\mathrm{PB}$, $\mathrm{pH}$ 6.5, using SPE, SPE/DDAB, SPE/CB/DDAB. Potential scan range is from 100 to $-600 \mathrm{mV}$ for $\mathrm{Mb}$ and from 500 to $-500 \mathrm{mV}$ for cyt $c$; scan rate, $50 \mathrm{mV} / \mathrm{s}$

the electrode surface, DDAB film was adsorbed on $\mathrm{CB} /$ SPE. As shown in Figure 2, CB layer dramatically increased the reduction and oxidation peaks of $\mathrm{Fe}$ (III)heme on SPE/CB/DDAB. With the SPE/CB/DDAB, cyt $c$ in solution demonstrated a more reversible redox process than with SPE/DDAB (Figure 2A).

Electrochemical reaction of cyt $c$ can be expressed according to Equation 1:

$\mathrm{P}-\mathrm{Fe}(\mathrm{III})+1 e \leftrightarrow \mathrm{P}-\mathrm{Fe}(\mathrm{II})$

where $\mathrm{P}-\mathrm{Fe}(\mathrm{III}) / \mathrm{P}-\mathrm{Fe}(\mathrm{II})$ is heme protein in $\mathrm{Fe}(\mathrm{III}) /$ $\mathrm{Fe}(\mathrm{II})$-state.

With $\mathrm{SPE} / \mathrm{CB} / \mathrm{DDAB}, E^{\circ \prime}$ for $\mathrm{Fe}$ (III)/Fe(II)-heme of cyt $c$ was found to be $71 \pm 5 \mathrm{mV}$, and $\Delta E_{\mathrm{p}}$ was equal to $68 \pm 5 \mathrm{mV}$ vs. $E^{\circ \prime}=-45 \pm 5 \mathrm{mV}$ and $\Delta E_{\mathrm{p}}=103 \pm 5 \mathrm{mV}$ for SPE/DDAB - with the scan rate, in both cases, being equal to $50 \mathrm{mV} / \mathrm{s}$. The current of the anodic and cathodic peaks of cyt $c$ increased linearly with the square root of the scan rate between $0.005-0.1 \mathrm{~V} / \mathrm{s}$, indicating that the process was diffusion controlled: $I_{\mathrm{p}, \mathrm{c}}(\mu \mathrm{A})=11.8 \pm 0.7-$ $184 \pm 9 \quad v^{1 / 2}(\mathrm{~V} / \mathrm{s})^{1 / 2} \quad$ and $I_{\mathrm{p}, \mathrm{a}} \quad(\mu \mathrm{A})=-11 \pm 1+211 \pm 13$ $v^{1 / 2}(\mathrm{~V} / \mathrm{s})^{1 / 2}(R=0.997, n=6, R S D=10 \%)$.

The CVs of $\mathrm{Mb}$ solution are presented in Figure 2B. With SPE/CB/DDAB, Mb had two well defined reduction and oxidation peaks. $\mathrm{Mb}$ (after one-electron reduction (Equation 1)) in $\mathrm{Mb}-\mathrm{Fe}(\mathrm{II})$-state fast binds oxygen (Equation 2) and autoxidized (Equation 3):

$$
\begin{aligned}
& \mathrm{P}-\mathrm{Fe}(\mathrm{II})+\mathrm{O}_{2} \rightarrow \mathrm{P}-\mathrm{Fe}(\mathrm{II})-\mathrm{O}_{2} \\
& \mathrm{P}-\mathrm{Fe}(\mathrm{II})-\mathrm{O}_{2} \rightarrow \mathrm{P}-\mathrm{Fe}(\mathrm{III})-\mathrm{O}_{2} \cdot{ }^{\cdot-} \rightarrow \mathrm{P}-\mathrm{Fe}(\mathrm{III})+\mathrm{O}_{2}^{\cdot-}
\end{aligned}
$$

With SPE/CB/DDAB, $E^{\circ \prime}$ for the $\mathrm{Fe}(\mathrm{III}) / \mathrm{Fe}(\mathrm{II})$-heme of $\mathrm{Mb}$ was found to be $-137 \pm 5 \mathrm{mV}$, and $\Delta E_{\mathrm{p}}$ was equal to $-101 \pm 5 \mathrm{mV}$, with the scan rate being $50 \mathrm{mV} / \mathrm{s}$. The current of the cathodic peak of $\mathrm{Mb}$ reduction on SPE/ $\mathrm{CB} / \mathrm{DDAB}$ and SPE/DDAB increased linearly with the square root of the scan rate. The slopes of curves $I_{\mathrm{p}, \mathrm{c}} \mathrm{vs}$. $v^{1 / 2}$ for the cathodic peaks of $\mathrm{Mb}$ reduction from their solutions on SPE/CB/DDAB and SPE/DDAB were found equal to $-(3.4 \pm 0.2) \times 10^{-5} \quad(0.005-0.1 \mathrm{~V} / \mathrm{s}) \quad$ and $-(2.2 \pm 0.1) \times 10^{-6}(0.005-0.03 \mathrm{~V} / \mathrm{s}) \mathrm{A} /(\mathrm{V} / \mathrm{s})^{1 / 2}$, respectively. From the above data it follows that $\mathrm{CB}$ promotes electroreduction process of cyt $c$ - $\mathrm{Fe}(\mathrm{III})$ and $\mathrm{Mb}-\mathrm{Fe}(\mathrm{III})$ in solutions.

In the course of biosensors development, $\mathrm{CB} / \mathrm{DDAB}$ was tested as an immobilization matrix for different heme proteins: cyt $c$, Mb, HRP, CYP 3A4, CYP 2B4, and CYP 51A1. Direct electrochemistry of thes heme proteins immobilized on SPE/CB/DDAB was observed. Heme proteins (P-Fe(III)) which formed a complex with oxygen in $\mathrm{P}-\mathrm{Fe}(\mathrm{II})$-state (Mb, HRP, CYPs) being immobilized on $\mathrm{SPE} / \mathrm{CB} / \mathrm{DDAB}$ demonstrated a similar behavior that of $\mathrm{Mb}$ in solution: the reduction peak increased and appeared to be more narrow, the oxidation peak also increased and became well defined compared to SPE/ DDAB. Figure 3 demonstrates the reduction-oxidation CVs of HRP and CYP 2B4 immobilized on SPE/CB/ DDAB. Electrochemical characteristics of direct electron transfer reactions of different heme proteins immobilized on SPE/CB/DDAB are presented in Table 2.

In case of cyt $c, \mathrm{CB}$ did not improve the redox process (Equation 1) characteristics of this protein: the signal-tonoise ratio for SPE/DDAB/cyt $c$ did not change significantly compared to SPE/CB/DDAB/cyt $c$.

The separation between $\mathrm{CV}$ reduction and oxidation peaks increases with increasing can rate, because of limiting electron-transfer kinetics. The $\Delta E_{\mathrm{p}}$, values were used to estimate the rate constants for electron transfer between electrodes and cyt $c$ by the method of Laviron [34]. Apparent surface electron transfer rate constants $\left(k_{\mathrm{s}}\right)$ for SPE/DDAB/cyt $c$ and SPE/CB/DDAB/cyt $c$ were calculated given that $\alpha=0.5$, the scan rate $50 \mathrm{mV} / \mathrm{s}$, and $\Delta E_{\mathrm{p}}(\mathrm{Fe}(\mathrm{III}) / \mathrm{Fe}(\mathrm{II}))<200 \mathrm{mV}$, they were estimated as $0.93 \pm 0.09 \mathrm{~s}^{-1}$ and $1.22 \pm 0.12 \mathrm{~s}^{-1}$, respectively. 


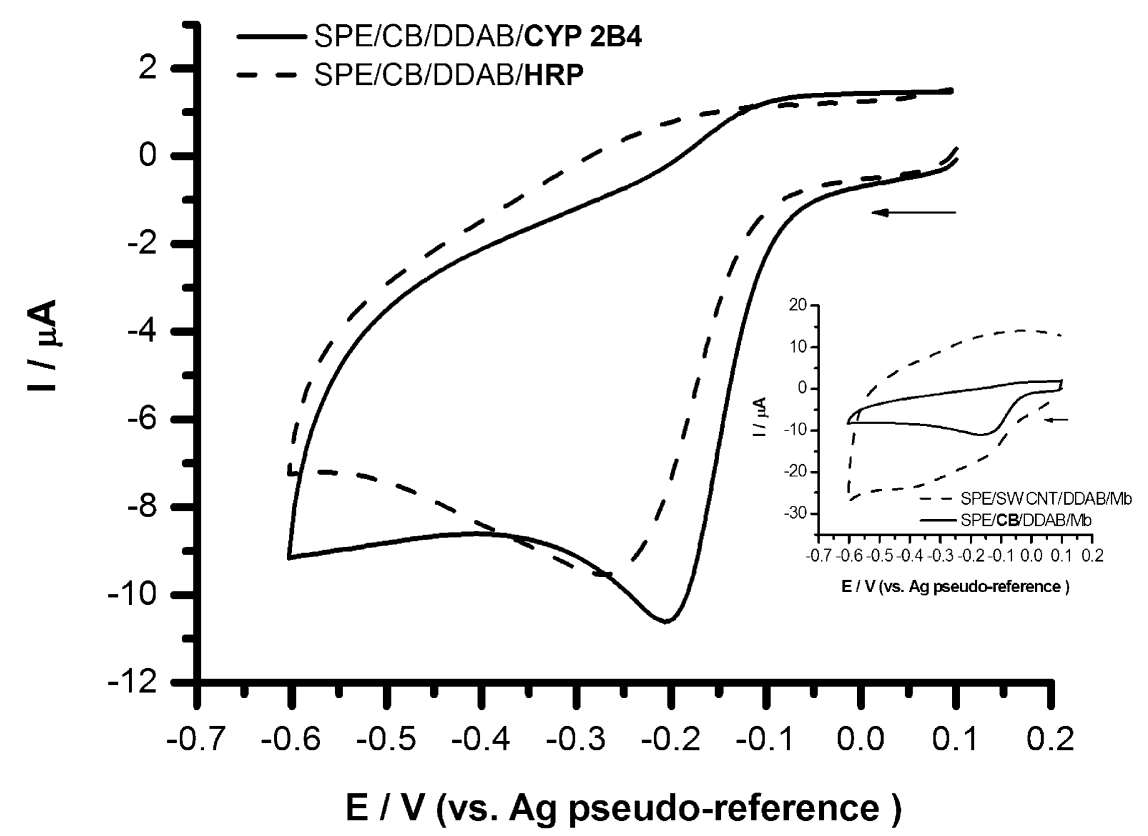

Fig. 3. CVs of SPE/CB/DDAB/imm. protein: $100 \mu \mathrm{M} \mathrm{CYP} 2 \mathrm{~B} 4(-)$ and $50 \mu \mathrm{M}$ HRP (- - -). Insert: CVs of 1mM Mb immobilized on: SPE/CB/DDAB (-) and SPE/SW CNT/DDAB (- - ). $0.25-\mu \mathrm{L}$ aliquots of $0.1 \mathrm{M}$ DDAB and heme proteins' solutions were taken. Potential range was from 100 to $-600 \mathrm{mV}$, scan rate, $50 \mathrm{mV} / \mathrm{s}$. $\mathrm{PB}, \mathrm{pH}$ 6.5.

Table 2. Electrochemical characteristics of the direct electron transfer reactions for cyt $c(1 \mathrm{mM}), \mathrm{Mb}(1 \mathrm{mM})$, HRP $(50 \mu \mathrm{M})$, CYP 3A4 $(165 \mu \mathrm{M})$, CYP 2B4 $(100 \mu \mathrm{M})$, and CYP51A1 $(165 \mu \mathrm{M})$ immobilized on DDAB/CB/SPE. Aliquots of heme proteins's solutions were $0.25 \mu \mathrm{L}$ per electrode. $\mathrm{CV}$, potential range from 100 to $-600 \mathrm{mV} ; 50 \mathrm{mV} / \mathrm{s}$. $\mathrm{PB}, \mathrm{pH} 6.5$.

\begin{tabular}{lllll}
\hline Heme protein & $E_{\mathrm{p}, \mathrm{c}}(\mathrm{V})$ & $E_{\mathrm{p}, \mathrm{a}}(\mathrm{V})$ & $\Delta E_{\mathrm{p}}(\mathrm{V})$ & $E^{\circ \prime}(\mathrm{V})$ \\
\hline Cyt $c$ & -0.032 & +0.020 & 0.052 & -0.006 \\
Mb & -0.186 & -0.048 & 0.138 & -0.117 \\
HRP & -0.267 & -0.159 & 0.109 & -0.213 \\
CYP 51A1 & -0.197 & -0.073 & 0.124 & -0.135 \\
CYP 3A4 & -0.267 & -0.130 & 0.137 & -0.199 \\
CYP 2B4 & -0.205 & -0.110 & 0.095 & -0.158 \\
\hline
\end{tabular}

The $\mathrm{k}_{\mathrm{s}}$ obtained for cyt $c$ immobilized on SPE/CB/ DDAB $\left(1.22 \pm 0.12 \mathrm{~s}^{-1}\right)$ is similar to that reported earlier for $\mathrm{Hb}$ adsorbed on the $\mathrm{CB}$ surface with an underlying glassy carbon electrode $\left(1.02 \mathrm{~s}^{-1}\right)[16]$. In this latter work the $\mathrm{Hb}$ molecules were adsorbed on the surface of $\mathrm{CB}$ powders during mixing. It is to be noted that $\mathrm{CB}$ powders were dispersed in $0.1 \mathrm{wt} \%$ solution of CTAB which, acting as a dispersant, allowed to prevent the $\mathrm{CB}$ powders aggregation following ultrasonication. In the cyclic voltammogram of the $\mathrm{Hb}-\mathrm{CTAB} / \mathrm{GC}$ electrode, no redox peaks were observed. Conversely, a pair of well-defined and nearly symmetrical redox peaks was obtained at the $\mathrm{Hb}-\mathrm{CB} / \mathrm{GC}$ electrode. Based on $\mathrm{CV}$ data, $\mathrm{Ma}$ and coworkers [16] concluded that direct electron transfer reaction of $\mathrm{Hb}$ is not promoted by the surfactant CTAB or Nafion but is rather promoted by CB due to the presence of the oxygen-containing groups and many active sites on the surface. However, based on researches by Rusling's group [17-20] and our above-cited results (see Figure 2) it was inferred that surfactants (DDAB, CTAB) play an important role in direct electron transfer reactions of heme proteins. Without DDAB, CB did not exhibited any catalytic properties towards heme proteins. It may well be that DDAB is able to hydrophilize hydrophobic CB and, hence, serves as a bridge between hydrophilic protein molecules and hydrophobic electrode surface.

The results obtained with the $\mathrm{DDAB} / \mathrm{CB}$ matrix for heme proteins' direct electron transfer are in close agreement with those reported earlier by C. Cai et al. [35]. Authors demonstrated that the direct electron transfer rate of $\mathrm{Hb}$ was significantly enhanced after immobilization of this heme protein onto the surface of CNT dispersed in the solution of the surfactant CTAB.

Based on: (i) the similar behavior of $\mathrm{CB}$ and CNT towards electroactive substances [31] and (ii) the electrochemical catalytic properties of surfactant films (DDAB, CTAB) exhibited towards heme proteins $[17,18]$, the $\mathrm{CB} /$ DDAB matrix was compared with SW CNT/DDAB with respect to direct electron transfer registration of immobilized $\mathrm{Mb}$ and cyt $c$. However, it is evident from the insert to Figure 3 that in air (i.e. without deoxygenation of solution) SW CNT in combination with DDAB is not suitable for heme proteins' redox activity registration and determination because of the unsatisfactory signal-to-noise ratio. It appears that with respect to electrocatalytic properties and the signal-to-noise ratio CNT, as an electrode surface modifier, yields to CB.

\subsection{Mb Calibration Curve}

$\mathrm{Mb}$ participates in human respiration both as an oxygen store and as an entity facilitating oxygen diffusion, there- 
by supporting cellular respiration in cardiac and skeletal muscle tissues. In addition to conventional functions, it can possibly act, as has been recently proposed, as an intracellular scavenger of nitric oxide (NO) to protect mitochondrial cytochrome $c$ oxidase from its inhibition by NO [1]. In healthy organism, in the absence of inflammation or injury of muscle tissues, myoglobin does not release into the circulation. Mb detection is very important for express diagnosis of acute myocardial infarction (cardiac isoform), crush syndrome, hypoxia neonatorum, overtraining of sportsmen, as well as in forensic medicine as an additional criterion for fatal poisoning with ethanol and drugs (skeletal muscle isoform).

To show that direct electron transfer reactions of heme proteins can be used not only for $\mathrm{H}_{2} \mathrm{O}_{2}$ or NO-biosensors construction, but also, what is more important, for direct detection of heme proteins in biological liquids, the SPE/ $\mathrm{CB} / \mathrm{DDAB}$ sensor was tested as a model for Mb determination in solutions. Aliquot of $\mathrm{Mb}$ buffer samples were placed onto the SPE/CB/DDAB sensors' surfaces. Sensors were allowed to stay for $15 \mathrm{~min}$ at $37^{\circ} \mathrm{C}$. Then electrochemical measurements were performed by SWV. The calibration curve of $\mathrm{Mb}$ reduction at the surface of SPE/ $\mathrm{CB} / \mathrm{DDAB}$ sensor is shown in Figure 4.

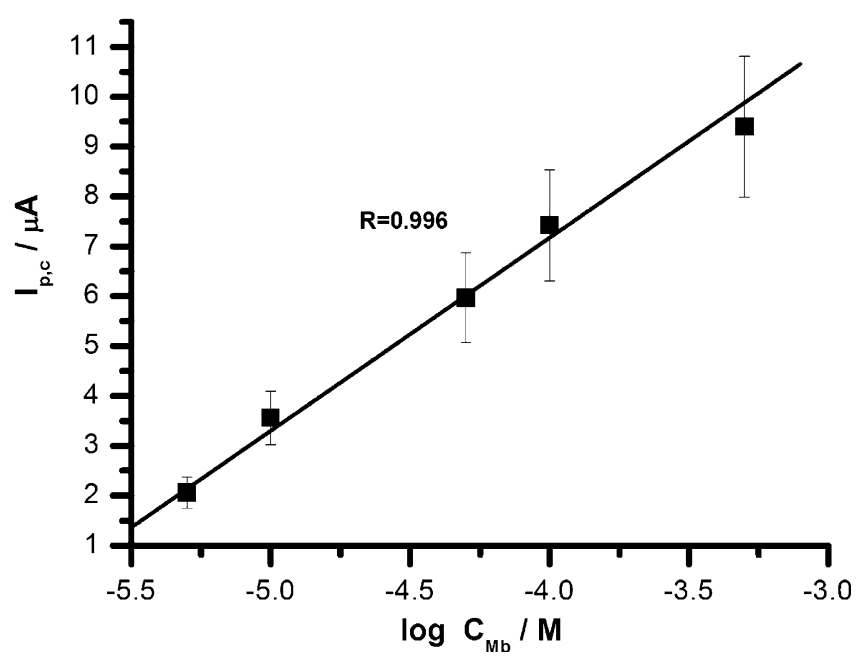

Fig. 4. Calibration curve of $\mathrm{Mb}$ detection with $\mathrm{SPE} / \mathrm{CB} / \mathrm{DDAB}$. Aliquots of $\mathrm{Mb}$ solutions were $0.25 \mu \mathrm{L} ; \mathrm{PB}, \mathrm{pH}$ 6.5. SWV: $E_{\mathrm{i}}=$ $0.1 \mathrm{~V} ; E_{\mathrm{e}}=-0.6 \mathrm{~V} ; \Delta E_{\mathrm{p}}=20 \mathrm{mV} ; \Delta E_{\mathrm{s}}=5 \mathrm{mV} ; f=10 \mathrm{~Hz}$.

The peak current variation $\left(I_{\mathrm{p}, \mathrm{c}}(\mu \mathrm{A})\right)$ vs. the logarithm of myoglobin concentration $\left(\log C_{\mathrm{Mb}}(\mathrm{M})\right)$ was linear within the range 5 to $500 \mu \mathrm{M}$. Its corresponding regression equation was $I_{\mathrm{p}, \mathrm{c}}(\mu \mathrm{A})=23 \pm 3+3.9 \pm 0.5 \log C_{\mathrm{Mb}}(\mathrm{M})$ $(R=0.996$ and $n=5)$. Relative standard deviation for three measurements was $15 \%$. The sensitivity of $\mathrm{Mb}$ determination with the SPE/CB/DDAB sensor was about an order higher than it was with the CB-unmodified sensor surface (data not shown). Therefore, the direct electron transfer reaction of $\mathrm{Mb}$ can be used for qualitative measurement of the heme protein from solution, and
CB can be effectively used as a modifier in electrochemical Mb-biosensors.

\section{5 cMb-Immunosensor (SPE/CB/DDAB/anti-cMb): Analysis of Human Blood Plasma Samples}

As an electrode surface modifier, $\mathrm{CB}$ was applied for $\mathrm{cMb}$-immunosensor construction. For this purpose, cMbantibodies were immobilized on the $\mathrm{CB} / \mathrm{DDAB}$ matrix. Plasma samples from healthy donors and patients with acute myocardial infarction were analyzed. Figure 5 pres-

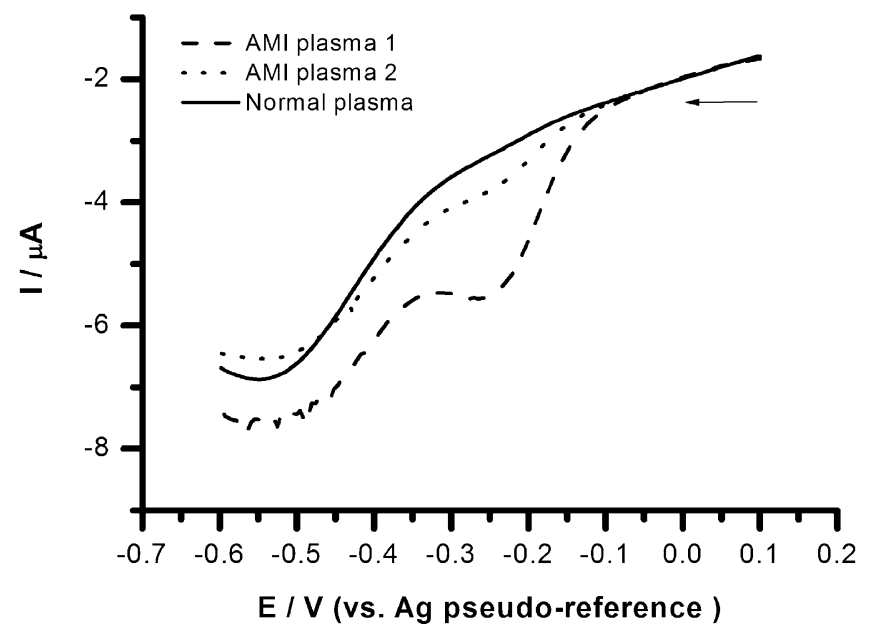

Fig. 5. SWVs of cMb reduction using SPE/CB/DDAB/anti-cMb immunosensors. Plasma samples from healthy donor and patients with myocardial infarction with $C(\mathrm{cMb})=350 \pm 35 \mathrm{ng} / \mathrm{mL}$ (AMI plasma 1) and $C(\mathrm{cMb})=190 \pm 19 \mathrm{ng} / \mathrm{mL}$ (AMI plasma 2) were analyzed. $0.25-\mu \mathrm{L}$ aliquots of plasma samples were used. SWVs were registered in $\mathrm{PB}, \mathrm{pH} 6.5$ at $E_{\mathrm{i}}=0.1 \mathrm{~V} ; E_{\mathrm{e}}=-0.6 \mathrm{~V} ; \Delta E_{\mathrm{p}}=$ $20 \mathrm{mV} ; \Delta E_{\mathrm{s}}=5 \mathrm{mV} ; f=10 \mathrm{~Hz}$.

ents typical SWVs of $\mathrm{Fe}(\mathrm{III})-\mathrm{cMb}$ reduction from the plasma sample registered with the SPE/DDAB/anti-cMb and SPE/CB/DDAB/anti-cMb sensors. Following CBmodification a one order increase in the cathodic peak currents was registered for $\mathrm{Mb}$ in human blood plasma samples (data not shown), which was in agreement with the data obtained for buffer samples with sensor without antibodies (SPE/CB/DDAB, Sectiom 3.4, Figure 4).

\section{Conclusions}

Commercially available CB N220 in combination with the surfactant DDAB was found to be a perspective matrix for investigation of the direct electron transfer between heme proteins and electrode. Well-shaped cathodic and anodic peaks were registered by $\mathrm{CV}$ and SWV on SPE/ $\mathrm{CB} / \mathrm{DDAB}$ electrodes for cyt $c, \mathrm{Mb}, \mathrm{HRP}$ and CYPs (both in solution and in immobilized state). The direct electrochemistry of heme proteins on CB/DDAB-modified electrodes allowed us to obtained a successfully-oper- 
ating immunosensor for cardiac myoglobin detection in human blood plasma.

The advantages of $\mathrm{DDAB} / \mathrm{CB}$ matrix for heme proteins' direct electron transfer registration were achieved due to a combination of such beneficial factors as electrocatalytic and hydrophilic properties of the liquid crystal surfactant DDAB, its good adsorptive capability, and the unique structural features of $\mathrm{CB}$. As a carbon electrode surface modifier in electroanalytical chemistry, $\mathrm{CB}$ can compete with SW CNT, especially with respect to the signal-to-noise ratio, simplicity of preparation of dispersion and low cost (around 1 euro per $1 \mathrm{~kg}$ ). Potential applications of electrochemical activity exhibited by HRP and CYPs involve the usage of HRP- and CYPs-catalyzed reactions for biosensors construction and for screening potential substrates and inhibitors of these heme proteins. $\mathrm{Mb}$ detection is highly necessary for express diagnosis of AMI (cardiac isoform) and other diseases and disease states. Cyt $c$ electrochemistry is important for investigation of the respiratory chain and for elucidation of the mechanism of heme proteins' autooxidation (as nonbinding oxygen control).

\section{Acknowledgement}

This work was financially supported by a scholarship of the Ministry of Foreign Affairs of Italy (Ministero degli Affari Esteri, DGPCC-Ufficio VI, a.a. 2010/2011).

\section{References}

[1] K. Shikama, Prog. Biophys. Molecular Biol. 2006, 91, 83.

[2] L. Gorton, A. Lindgren, T. Larsson, F. D. Munteanu, T. Ruzgas, I. Gazaryan, Anal. Chim. Acta 1999, 400, 91.

[3] A. A. Karyakin, Bioelectrochemistry 2012, 88, 70.

[4] F. W. Scheller, N. Bistolas, S. Liu, M. Jänchen, M. Katterle, U. Wollenberger, Adv. Colloid. Interf. Sci. 2005, 116, 111.

[5] N. Bistolas, U. Wollenberger, C. Jung, F. W. Scheller, Biosens. Bioelectron. 2005, 20, 2408.

[6] E. E. Ferapontova, Electroanalysis 2004, 16, 1101.

[7] R. L. McCreery, Chem. Rev. 2008, 108, 2646.

[8] I. V. Berezin, V. A. Bogdanovskaya, S. D. Varfolomeev, M. R. Tarasevich, A. I. Yaropolov, Dokl. Akad. Nauk SSSR 1978, 240, 615.
[9] F. Arduini, F. Di Giorgio, A. Amine, F. Cataldo, D. Moscone, G. Palleschi, Anal. Lett. 2010, 43, 1688.

[10] S. B. Hocevar, B. Ogorevc, Talanta 2007, 74, 405.

[11] F. Arduini, A. Amine, C. Majorani, F. Di Giorgio, D. De Felicis, F. Cataldo, D. Moscone, G. Palleschi, Electrochem. Commun. 2010, 12, 346.

[12] F. Arduini, F. Di Nardo, A. Amine, L. Micheli, G. Palleschi, D. Moscone, Electroanalysis 2012, 24, 743.

[13] F. Arduini, C. Majorani, A. Amine, D. Moscone, G. Palleschi, Electrochim. Acta 2011, 564209.

[14] A. Liberti, C. Morgia, M. Mascini, Anal. Chim. Acta 1985, $173,157$.

[15] J. Razumiene, J. Barkauskas, V. Kubilius, R. Meskys, V. Laurinavicius, Talanta 2005, 67, 783.

[16] G-X Ma, T-H Lu, Y-Y Xia, Bioelectrochemistry 2007, 71, 180.

[17] J. F. Rusling, Microporous Mater. 1994, 3, 1.

[18] J. F. Rusling, A.-E. F. Nassar, J. Am. Chem. Soc. 1993, 115, 11891.

[19] P. M. Guto, J. F. Rusling, Electrochem. Comm. 2006, 8, 455.

[20] Z. Lu, Q. Huang, J. F. Rusling, J. Electroanal. Chem. 1997, $423,59$.

[21] J. E. B. Randles, Discuss. Faraday Soc. 1947, 1, 11.

[22] I. I. Karuzina, V. G. Zgoda, G. P. Kuznetsova, N. F. Samenkova, A. I. Archakov, Free Radic. Biol. Med. 1999, 26, 620.

[23] T. Omura, R. Sato, J. Biol. Chem. 1964, 239, 2379.

[24] E. V. Suprun, A. L. Shilovskaya, A. V. Lisitsa, T. V. Bulko, V. V. Shumyantseva, A. I. Archakov, Electroanalysis 2011, 23,1051 .

[25] A. N. Ivanov, R. R. Younusov, G. A. Evtugyn, F. Arduini, D. Moscone, G. Palleschi, Talanta 2011, 85, 216.

[26] E. Suprun, T. Bulko, A. Lisitsa, O. Gnedenko, A. Ivanov, V. Shumyantseva, A. Archakov, Biosens. Bioelectron. 2010, 25, 1694.

[27] G. L. Turdean, I. C. Popescu, A. Curulli, G. Palleschi, Electrochim. Acta 2006, 51, 6435 .

[28] R. S. Nicholson, Anal. Chem. 1965, 37, 1351.

[29] J.-S. Ye, Y. Wen, W. D. Zhang, H.-F. Cui, L. M. Gan, G. Q. Xu, F.-S. Sheu, J. Electroanal. Chem. 2004, 562, 241.

[30] R. R. Moore, C. E. Banks, R. G. Compton, Anal. Chem. 2004, 76, 2677.

[31] L. Agu, P. Yanez-Sedeno, J. M. Pingarron, Anal. Chim. Acta 2008, 622, 11.

[32] C. E. Banks, T. J. Davies, G. G. Wildgoose, R. G. Compton, Chem. Commun. 2005, 7, 829.

[33] R. O. Kadara, N. Jenkinson, C. E. Banks, Sens. Actuators B 2009, $138,556$.

[34] E. Laviron J. Electroanal. Chem. 1979, 101, 19.

[35] C. Cai, J. Chen, Anal. Biochem. 2004, 325, 285. 